\title{
Pollen types used by Centris (Hemisiella) tarsata Smith (1874) (Hymenoptera, Apidae) in the provisioning of brood cells in an area of Caatinga
}

Ana Paula Araújo da Cruz ${ }^{1 *}$, Marcos da Costa Dórea ${ }^{2}$ and Luciene Cristina Lima e Lima ${ }^{1}$

Received: January 8, 2015 Accepted: March 06, 2015

\begin{abstract}
The aim of this study was to identify, by sediment pollen analysis, the plant species used as floral resources for the provisioning of brood cells in Centris (Hemisiella) tarsata, in an area of Caatinga, within the municipality of Nova Soure, Bahia State, Brazil. The analysis of pollen contents from three brood cells revealed 11 pollen types, corresponding to four botanical families. Malpighiaceae was represented most, followed by Leguminosae, Ochnaceae, and Solanaceae, the latter two represented by just a single pollen type each. On the basis of the percentages in the samples, it was possible to infer that $C$. tarsata visited distinct plants, but intensified its pollen collection in species related to Aeschynomene martii and Solanum paniculatum pollen types, which are considered the most important pollen sources in the larval diet of this bee. In addition to the pollen sources, we have also recorded seven pollen types regarded as oil ones, all related to the Malpighiaceae family. The information about the resources for C. tarsata can be of great relevance, in view of the importance of these bees in the pollination of native flora.
\end{abstract}

Keywords: entomopalynology, floral resources, semi-arid, solitary bees, trap nests.

Palynological analysis is an important tool in the study of bee food resources, in addition to its use in the determination of the foraging spectrum and the floral resources used by bees. This is possible because of the usage of pollen grains as natural markers, which are readily distinguishable in samples and do not deteriorate rapidly with time (Jones \& Jones 2001).

Palynological analyses of floral resources used by solitary bees in their nests are scarce in the literature. Within the Caatinga vegetation, few studies were performed analyzing the palynological spectrum in nests of Centris Fabricius, 1804 (Dórea et al. 2009; 2010a; b; 2013; Santos et al. 2013). Thus, we aimed to study the diversity of floral resources used by Centris (Hemisiella) tarsata Smith, 1974, using their nest sediment within an area of Caatinga in northeastern Brazil.

This study was performed in an area of Caatinga vegetation in Fazenda Pocinho, located in the municipality of
Nova Soure $\left(11^{\circ} 14^{\prime} 00^{\prime \prime}\right.$ S, $38^{\circ} 29^{\prime} 00^{\prime \prime}$ W), in the northeast of Bahia State. Trap nests were employed to induce nesting (Serrano \& Garófalo 1978), using perforated plaques with 56 holes, suspended by wires in wood frames approximately $1.5 \mathrm{~m}$ above soil, in which every hole was filled with tubes of black cardboard $(0.8 \times 10.5 \mathrm{~cm})$, with one of the extremities closed.

Trap nests were checked monthly between January 2012 and August 2013. Nests were properly sealed, identified, and taken to Laboratório de Estudos Palinológicos at Universidade do Estado da Bahia (LEP-UNEB). After emergence, the bees were identified by specialists and deposited at Museu de Zoologia of Universidade Federal da Bahia (MZUFBA).

Sampling efforts resulted in the collection of 36 nests, with emergence recorded for a single nest, in which just three specimens of Centris tarsata emerged. We used post-

\footnotetext{
${ }^{1}$ Departamento de Ciências Exatas e da Terra, Universidade do Estado da Bahia, Campus II, Rodovia Alagoinhas/Salvador, BR 110, Km 03, PO Box 59, 48040-210, Alagoinhas, BA, Brazil

${ }^{2}$ Departamento de Ciências Biológicas, Universidade Estadual de Feira de Santana, Transnordestina, s/n, Novo Horizonte, 44036-900, Feira de Santana, BA, Brazil

*Corresponding author: paula_aurus@hotmail.com
} 
emergence residues of this nest, which had its brood cells individualized. Only brood cells that generated a bee specimen were taken into account in this study. Samples were initially submitted to the protocol of Dórea et al. (2009) followed by acetolysis (Erdtman 1960). The sediment obtained was mounted on slides for optical microscopy analysis. Qualitative analysis was performed for pollen type identification, using specialized literature (Roubik \& Moreno 1991; Carreira et al. 1996; Carreira \& Barth 2003; Melhem et al. 2003; Silva et al. 2010). For quantitative analysis, we counted 1,000 pollen grains per sample (minimum), in which pollen type frequencies were calculated for each sample, as well as the frequency of occurrence for each of them (Vergeron 1964; Villanueva-Gutiérrez \& Roubik 2004).

The diversity of pollen types in the samples was evaluated using Shannon's index $\left(H^{\prime}\right)$ (Shannon 1948). Pielou's equitability index $(J)$ (Pielou 1977) was used to indicate the dynamics of the use of pollen resources by bees. We used Morisita's coefficient (Morisita 1959) for similarity analysis. All analyses were performed using PAST (Palaeontological Statistics) software version 2.15 (Hammer et al. 2001).

The analysis of the pollen spectrum in three brood cells identified 11 pollen types, corresponding to four plant families (Tab. 1), and 100\% from this total had its botanical affinities identified. Among these plant families, Malpighiaceae was the most represented with respect to the richness of pollen types (seven), followed by Leguminosae (2), and Ochnaceae and Solanaceae represented by a single pollen type each (Tab. 1). The number of pollen types on samples varied from five (sample II) to eight (sample III). Four pollen types were represented with a frequency of less than $1 \%$ and occurred sparsely just in a single sample. The highest frequencies were recorded for Aeschynomene martii and Solanum paniculataum, varying from $0.62 \%$ to $91.63 \%$ and $7.38 \%$ to $95.06 \%$, respectively, both with a frequency of occurrence of $100 \%$ (Tab. 1).

The diversity index for Centris tarsata was $H^{\prime}=0.71$, indicating that this species visited a relatively low number of plants to obtain floral resources, whereas its equitability index was $J^{\prime}=0.29$, showing that it focused its pollen foraging on a few plant species, related to the pollen types of $A$. martii and $S$. paniculatum, which showed the highest frequencies in the samples (Tab. 1). The species related to these pollen types were considered the main trophic resources for this bee species in the period studied. During the provisioning period in the nest, there appears to have been a change in the supply of pollen. This can be inferred by observing the decrease in the frequency of $A$. martii type pollen samples and the increased frequency of S. paniculatum. According to Carvalho \& Marchini (1999), the variation in the number of pollen types, their frequencies in samples, and the frequency of occurrence may be related to changes in pollen

Table 1. Pollen types recorded in nests of Centris (Hemisiella) tarsata Smith (1874), within an area of Caatinga in the municipality of Nova Soure, Bahia State. Frequency of samples (\%), frequency of occurrence (FO).

\begin{tabular}{|c|c|c|c|c|}
\hline \multirow{2}{*}{ Pollen types } & \multicolumn{3}{|c|}{ Samples } & \multirow{2}{*}{ FO } \\
\hline & I & II & III & \\
\hline \multicolumn{5}{|l|}{ Leguminosae-caesalpinioideae } \\
\hline Poincianella & & & 0.21 & 33.33 \\
\hline \multicolumn{5}{|l|}{ Leguminosae-papilionoideae } \\
\hline Aeschynomene martii & 91.63 & 74.07 & 0.62 & 100.00 \\
\hline \multicolumn{5}{|l|}{ Malpighiaceae } \\
\hline Banisteriopsis & 0.3 & 0.39 & 1.44 & 100.00 \\
\hline Byrsonima sericea & 0.08 & & & 33.33 \\
\hline Heteropterys type 1 & 0.38 & 1.09 & 0.82 & 100.00 \\
\hline Heteropterys type 2 & 0.08 & & 0.62 & 66.66 \\
\hline Malpighia emarginata & & & 0.82 & 33.33 \\
\hline Malpighiaceae type 1 & 0.15 & & & 33.33 \\
\hline Stigmaphyllon & & 0.31 & & 33.33 \\
\hline \multicolumn{5}{|l|}{ Ochnaceae } \\
\hline Ouratea & & & 0.41 & 33.33 \\
\hline \multicolumn{5}{|l|}{ Solanaceae } \\
\hline Solanum paniculatum & 7.38 & 24.14 & 95.06 & 100.00 \\
\hline Number of pollen types & 7 & 5 & 8 & \\
\hline \multicolumn{5}{|l|}{ Diversity index (H') 0.71} \\
\hline Equitability index (J') 0.29 & & & & \\
\hline
\end{tabular}


and nectar production by the plant because of climatic factors, besides differences in strategies for collecting and specific floral preferences of each species.

The importance of Leguminosae and Solanaceae in the diet of Centris in Caatinga was also observed in other studies. Dórea et al. (2009; 2010b) identified the species related to the pollen types of $S$. paniculatum, Senna rizzini and Chamaecrista ramosa as the main trophic resources for Centris tarsata, by analysis of pollen residues in the nests of this species in the Caatinga of Canudos municipality, Bahia State. Santos et al. (2013) performed a palynological analysis in the nests of Centris (Heterocentris) analis Fabricius, 1804, in a study within an area of Caatinga in the municipality of Feira de Santana, showing species related to the pollen types of Cajanus cajan and S. paniculatum as the main trophic resources for this bee species.

We recorded seven pollen types related to species of oil flowers: Banisteriopsis, Byrsonima sericea, Heteropterys type 1, Heteropterys type 2, Malpighia emarginata, Malpighiaceae type 1, and Stigmaphyllon. Malpighiaceae is cited in several studies as one of the main oil resources for Centris in Caatinga (Aguiar 2003; Aguiar et al 2003; Dórea et al. 2009; 2010a; 2010b; 2013; Santos et al. 2013). Floral oils are also considered as a crucial floral resource for Centris, being used in the feeding of larvae and/or the construction of nests (Vogel 1974).

Even though all samples were from the same nest, we observed different similarity indexes among them. The highest similarity indexes were observed between samples I and II (IS $=96 \%$ ), which had four pollen types in common (A. martii, Banisteriopsis, Heteropterys type 1, and $S$. paniculatum), indicating a higher intensity of exploitation of the few floral resources.

Knowledge of the trophic resources for solitary bees, such as Centris tarsata, is of great importance for the comprehension of animal/plant relations in threatened biomes, as in the Caatinga, assisting in conservation biology studies of both plants and their pollinators.

\section{Ackowledgements}

We thank Fundação de Amparo a Pesquisa do Estado da Bahia (FAPESB) for the scholarship granted to the first author, Universidade do Estado da Bahia and Programa de Pós-Graduação Biodiversidade Vegetal for the lab facilities used in this work, Dr. Favizia Freitas de Oliveira for the bee identifications, and to Dr. Mara Rojane Matos for the collaboration with statistical analysis.

\section{References}

Aguiar CML. 2003. Utilização de recursos florais por abelhas (Hymenoptera, Apoidea) em uma área de caatinga (Itatim, Bahia, Brasil). Revista Brasileira de Zoologia 20: 457-467.
Aguiar CML, Zanella FCV, Martins CF, Carvalho CAL. 2003. Plantas visitadas por Centris spp. (Hymenoptera: Apidae) na caatinga para obtenção de recursos florais. Neotropical Entomology 32: 247-259.

Carreira LMM, Barth OM. 2003. Atlas de pólen: da vegetação da canga da Serra dos Carajás. Belém, Goeldi Editoração.

Carreira LMM, Silva MF, Lopes JRC, Nascimento LAS. 1996. Catálogo de pólen das leguminosas da amazônia brasileira. Belém, Goeldi Editoração.

Carvalho CAL, Marchini CL. 1999. Tipos polínicos coletados por Nannotrigona testaceicornis e Tetragonisca angustula (Hymenoptera, Apidae, Meliponinae). Scientia. Agricola 56(30).

Dórea MC, Aguiar CML, Figueroa LHF, Lima LCL, Santos, FAR. 2010a. Residual pollen in nest of Centris analis (Hymenoptera, Apidae, Centridini) na área of caatinga vegetation from Brazil. Oecologia Australis 14: 232-237.

Dórea MC, Aguiar CML, Figueroa LHF, Lima LCL, Santos, FAR. 2010b. Pollen residues in nests of Centris tarsata Smith (Hymenoptera, Apidae, Centridini) in a tropical semiarid area in NE Brazil. Apidologie 41: 557-567.

Dórea MC, Aguiar CML, Figueroa LHF, Lima LCL, Santos, FAR. 2013. A study of pollen residues in nest of Centris trigonoides Lepeletier (Hymenoptera, Apidae, Centridini) in Caatinga vegetation, Brazil. Grana 52: 122-128.

Dórea MC, Santos FAR, Lima LCL, Figueroa, LHR. 2009. Análise Polínica do Resíduo Pós-Emergência de Ninhos de Centris tarsata Smith (Hymenoptera: Apidae, Centridini). Neotropical Entomology 38: 197-202.

Erdtman G. 1960. The acetolysis method. A revised description. Svensk Botanisk Tidskrift 39: 561-564.

Hammer O, Harper DAT, Ryan PD. 2001. PAST: Paleontological Statistics Software Package for Education and Data Analysis. Palaeontologia Electronica 4: 1-9.

Jones DG, Jones SD. 2001. The uses of pollen and its implication for entomology. Neotropical Entomology 30: 341-350.

Melhem TS, Cruz-Barros MAV, Corrêa MAS, Makino-Watanabe HSM, Silvestre-Capelato MSF, Esteves VLG. 2003. Variabilidade polínica em plantas de Campos do Jordão (São Paulo, Brasil). São Paulo, Instituto de Botânica de São Paulo.

Morisita M. 1959. Measuring the dispersion and the analysis of distribution patterns. Memoires of the Faculty of Science, Kyushu University, Series E. Biology 2: 215-235.

Pielou EC. 1977. Mathematical ecology. New York, Willey-Interscience Publication.

Roubik DW, Moreno JEP. 1991. Pollen and spores of Colorado Island. Estados Unidos da América, Monographs in Systematic Botany from.

Santos RM, Aguiar CML, Dórea MC, Almeida GF, Santos FAR, Augusto SC. 2013. The larval provisions of the pollinattor Centris analis pollen espectroand tropic niche breadt in na agroecossistem. Apidologie 44: 630-641.

Serrano JC, Garófalo CA. 1978. Utilização de ninhos artificiais para o estudo bionômico de abelhas e vespas solitárias. Ciência e Cultura 30: $597-598$

Shannon CE. 1948. A mathematical theory of communication. San Diego, Bell System Technical Journal.

Silva CI, Ballesteros PLO, Palmero MA, Bauermann SG, Evaldt ACP, Oliveira PE 2010. Catálogo polínico: Palinologia aplicada em estudos de conservação de abelhas do gênero Xylocopa no Triângulo Mineiro. Uberlândia, Minas Gerais, EDUFU.

Vergeron P. 1964. Interprétation statistique des résultats en matiére d'analyse pollinique des miels. Annals Abeille 7: 349-364.

Villanueva-Gutiérrez R, Roubik DW. 2004. Pollen sources of llong-tongued solitary bees (Megachilidae) in the biosphere reserve of Quitana Rôo, México. In: Freitas BM, Pereira JOP. (eds.) Solitary bees: conservation, rearing a management for pollination. Fortaleza, Imprensa Universitária, UFC. p. 185- 190.

Vogel S. 1974. Ölblumen und ölsammelnde Bienen. Akademie der Wissenchaften und der Literatur Tropische und subtropische. Pflanzenwelt $7: 285-547$. 